\title{
THE "COMPREHENSIVE VILLAGE RENEWAL PROGRAMME IN BURGERLAND" AS A MEANS OF STRENGTHENING THE SOCIAL CAPITAL IN RURAL AREAS
}

\author{
Doris Damyanovic ${ }^{1}$, Florian Reinwald ${ }^{2}$
}

Received 26 November 2012; Accepted 20 September 2013

\begin{abstract}
In this paper, the results of the study of the comprehensive village renewal programme in Burgenland are considered in the light of the concept of social capital. Changes to the social structures and demographic changes have a strong impact on the formation of social capital in the villages and are therefore a central challenge facing the policies of the municipalities. An objective in the further development of the programme for comprehensive village renewal is to strengthen the local and regional social capital. The implementation of participative village renewal processes has the potential for increasing social capital in the villages, but certain conditions need to be in place for this. The paper analyses and discusses how the programme has contributed to date to the formation of social capital, what opportunities the municipalities have and what instruments they will need in future to build up the social capital that is crucial to sustainable village development.
\end{abstract}

Keywords: Village renewal programme, social capital, Local Agenda 21, demographic change, participation, rural development

Zusammenfassung: In diesem Beitrag werden die Ergebnisse der Studie zum Programm umfassende Dorferneuerung im Burgenland unter dem Aspekt des Sozialkapitalkonzepts reflektiert. Veränderungen der gesellschaftlichen Strukturen sowie demografische Veränderungen haben einen starken Einfluss auf die Bildung des Sozialkapitals in den Dörfern und sind daher eine zentrale Herausforderung für die Kommunalpolitik. Ein Ziel für die Weiterentwicklung des Programms der umfassenden Dorferneuerung ist die Stärkung des lokalen und regionalen Sozialkapitals. Die Durchführung von partizipativen Dorferneuerungs- prozessen hat das Potential das Sozialkapital in den Dörfern zu steigern, dafür sind aber gewisse Voraussetzungen notwendig. Im Artikel wird analysiert und diskutiert, welchen Beitrag das Programm bisher zur Bildung von Sozialkapital geleistet hat und diskutiert, welche Möglichkeiten die Gemeinden haben und welche Instrumente sie

\footnotetext{
${ }^{1}$ DI Dr Doris Damyanovic, Institute of Landscape Planning, Department of Landscape, Spatial and Infrastructure Sciences, University of Natural Resources and Life Sciences, Vienna, Peter Jordan Strasse 65, 1180 Vienna, Austria, e-mail: doris.damyanovic@boku.ac.at

2 DI Florian Reinwald, Institute of Landscape Planning, Department of Landscape, Spatial and Infrastructure Sciences, University of Natural Resources and Life Sciences, Vienna, Peter Jordan Strasse 65, 1180 Vienna, Austria, e-mail: florian.reinwald@boku.ac.at
} 
zukünftig brauchen, um das lokale Sozialkapital, welches für eine nachhaltige Dorfentwicklung entscheidend ist, aufzubauen.

\section{Introduction}

One of the aims of the study on the 'Comprehensive Village Renewal Programme in Burgenland' (Umfassende Dorferneuerung im Burgenland) was to identify future prospects for the development of rural areas. The survey identified 'generations and families - local social capital and voluntary work' as one of the five key topics for the future development of the programme (Damyanovic and Reinwald, 2011).

Changes in social structures and demographic changes are challenges for local governments and thus are seen as a central task for the future development of the municipalities and the village renewal programme itself. Support for the formation of regional and local social capital (Bourdieu, 1983, Putnam, 1993, Gehmacher, 2009, Elbe, 2011) as well as the expansion and increased support for activities in the sector of neighbourly help are perceived as a solution to problems arising from demographic changes. The study shows that municipalities with similar underlying conditions and challenges develop differently. Some municipalities develop positively, with innovative projects implemented by the local population working together to achieve a positive future for the village, while in other municipalities this kind of development does not happen. Similar phenomena are also described by Putnam (1993) in his study of regions in Italy; he showed that the existing forms of social capital are a deciding factor in democratic development. In this context he speaks of the equipping of the region or municipalities with positive or negative social capital, which is expressed above all in a level of generalised trust or mistrust (Putnam/Gross, 2001, Elbe, 2011).

In this paper the basic assumption is that the social capital concept is a possible way of explaining these differences. The reflection on the results of the study is undertaken in this light. To begin with, the theoretical approach and its application in participative planning processes is shown.

The paper mainly describes the framework which this programme has already provided for support community members in increasing their common social capital. It goes on to discuss which possibilities and tools municipalities have for strengthening local social capital in future for sustainable village development.

\section{Social capital in the context of village renewal processes}

To begin with, the theoretical background underlying the social capital concept of the survey will be described. The definition of the term "social capital", as well as the importance and development of the general discourse, are taken as a starting point to show the way this socioeconomic concept is applied in planning and participation processes for the development of rural areas. Approaches for the analysis and measurement of social capital are also presented.

The term "social capital" has been in use since the 19th century, as described in a comprehensive review of social capital's conceptual history by political scientist James Farr (2004). Furthermore Farr believes that it was Lydia J. Hanifan who first used the term in a modern sense in her analysis of community in rural districts. Putnam (1993) also refers to the previous work of Hanifan. The works of urban sociologist Jane Jacobs (1961) are also quoted (Field, 2004) as an important contribution to the development of this concept of social capital. The contemporary significance of the term "social capital" came about in the second half of the last century, mainly in the 1980s and 1990s. It evolved from a sociological explanation of structural changes in education, economics and politics. The following three researchers Bourdieu, Coleman and Putnam - are often emphasised in connection with the development of the term (Falk and Kilpatrick, 2000; Field, 2008; Gehmacher, 2009; Elbe, 2011; Husák, 2012).

In the 1980s the French sociologist Bourdieu (1983) used the term to describe and understand the emergence and reproduction of social differences in society. The development of potential is placed at the individual level, but is influenced or determined by wider social conditions. 
The basis of the production of social capital is networks, which work on trust and reciprocity. Bourdieu (1991) also differentiates between different kinds of capital: cultural, economic, functional, linguistic, personal, political, professional, social and symbolic. The American sociologist Colemann (1988) describes the impact of social capital in the context of the education system. He focuses on the impact of social capital on the development of children and young people, and their educational opportunities. The American political scientist Putnam (1993) develops his concept of social capital in a long-term study in which he evaluates the effectiveness of regional administrations in Italy. Despite the differences, all three consider that social capital consists of personal connections and interpersonal interaction, together with the shared sets of values that are associated with these contacts (Field, 2008:15).

Putnam's approach (1993) points the way in considering the issue of rural regional development. He assumes that the ideas of association and civic activity form the basis of social integration and well-being. Later, Groottaert and Van Bastelaer (2002) also define social capital broadly as the institutions, relationships, attitudes and values that govern interactions between people and contribute to economic and social development. Axhausen (2008) formulates the term "social capital" in a planning context as the attempt to understand differences in economic performance, but also differences in performance in daily life between groups of people, or the populations of different cities, regions and even countries. To sum up, social capital can be said to have a benefit for the individual members of a network, but also, as a further consequence, a value to society as a whole. As can be seen from the discussion, it is apparent that the quality of the social capital depends to a great extent on the individual and collective use of orientation, which influences the network structure and the quality of the mutual standards and values. Social capital has various forms and defining features, which can be described and analysed.

Around the turn of the millennium this concept was also taken up by the global organisations of the World Bank and the Organisation for Economic Co-operation and Development (OECD) for fighting poverty in transition economies and for sustainable development (e.g. World Bank 2000; Groottaert and Van Bastelaer, 2002). In particular, however, a measurement of these social networks backed up by research was prompted as an instrument for the market economy and democracy. This refers back to the writings of Putnam (2000), who made it clear in his work that social capital - he talks in this context of various types of social capital - must be described in qualitative terms as well as being quantitatively measured. A decisive factor is the analysis of what types of social capital exist, who the persons involved are, what form the distribution takes, how it is created and how it changes over the course of time (Putnam and Gross, 2001).

Social capital is characterised by the duality of its characteristics (Elbe, 2011: 79). This duality is found in various forms of social capital, as well as in the various ways in which the individual forms have an impact. The range of social capital is regularly subdivided into the micro, meso and macro levels. The micro level, also called the individual level, denotes the relationship within the family and inner circle of friends, the meso level - the group level - describes the social networks outside the family and the inner circle of friends and the macro level is the organisational, institutional societal level of connectivity (Falk and Kilpatrick, 2000; Groottaert and Van Bastelaer, 2002; Gehmacher, 2009). This classification has been decided upon in order to take account of the complexity involved in seeking to determine the opportunities and risks associated with the use and promotion of the resource. Furthermore, two main dimensions are distinguished to describe the network view for the production of social capital. On one hand there is the bonding social capital, which describes the inner connectivity of the group, organisation or community. Social capital is often placed in groups and organisations and is understood as the "glue" that binds people together (Husák, 2012: 242). Groups with bonding social capital tend to be focused inwards and have a more homogeneous composition. In such groups identity is formed by outward definition, possibly including along ethnic lines. Defining features are a strong internal bond and high levels of loyalty. The other type is bridging social capital, which connects the inside community with the outside. Groups that have this kind of social capital form and maintain external contacts, and there is a higher flow of information (Elbe, 2011). Both dimensions are important for the sustainable development of social capital in a village or community. 
In theoretical and practical discourse on rural development it can be observed that the strengthening of social capital by (planning) policies is gaining in significance (Falk and Kilpatrick, 2000; Husák, 2010; Elbe, 2011). It is possible to state that a sufficient amount of social capital is a prerequisite for the development of regions and localities (Husák, 2012: 243).This can be seen in the politics of global organisations (Groottaert and Van Bastelaer, 2002; Field, 2008; Gehmacher, 2009), and in European and national projects and initiatives. In the development of rural areas, the focus lies increasingly on the development of local social capital as a key factor for sustainable community development (e.g. Gehmacher, 2009, Office of the State of Vorarlberg, 2010, Austrian Federal Ministry for Education, Arts and Culture et al., 2010). This also applies on a European level - 2011 was the "European Year of Volunteering".

To summarise, it should be said that social capital is not a fact nor a classical measurable resource in village renewal. Rather, social capital brings together connected social functional mechanisms which generate added value within and for a society. This capital arises and is accumulated through specific work on relations and networking. The social capital concept is the basis for die Local Agenda 21 Programme, which involves the development of strategies through 'bottom-up' participation (Dangschat et al. 2002; Hanke, 2011; Elbe, 2011). In particular, participation and citizen engagement is also viewed as an indicator of social capital (Putnam, 1993; Falk and Kilpatrick, 2000; Groottaert and Van Bastelaer, 2002; Gehmacher, 2009; Elbe, 2011). In order to be able to describe the benefits of the social capital of a community in a comprehensive village renewal process, it is assumed that different forms of social capital can be considered as local social capital if the individual and collective benefits they generate correspond to the objectives of the comprehensive village renewal. The forms of capital refer to the three levels previously described (those of the individual, the group, and society as a whole) and their two dimensions of action (bonding and bridging social capital). This capital arises and is accumulated through the participative village renewal process.

\section{The comprehensive village renewal programme as an instrument for meeting the challenges of the development of rural areas}

The comprehensive village renewal programme is an instrument for the promotion of lasting, sustainable village development, which should support the municipalities in meeting current challenges. The basis for the comprehensive village renewal in Burgenland programme (and the LEADER programme which supports the program) is the 'Local Agenda 21' strategy for establishing sustainable development. 'Local Agenda 21' designates the sustainability strategy specified by the European cities and towns at the conference in Aalborg in 1994. This Charter places decision-making and implementation at municipality level, as it is here that the (environmental) problems are first perceived and it is the level most accessible to citizens.

Cooperation and the involvement of all form the basis for giving all citizens access to information and enabling them to contribute to the local decision-making processes on development of the municipality.

Village renewal in Burgenland has been under way since 1987. Until the introduction of comprehensive village renewal in 2007, the emphasis was on the built environment in particular, and was mainly concerned with the promotion of house façades and the design of streets and squares in the villages. The comprehensive village renewal programme combines the 'Local Agenda 21' approach and that of structural village renewal. This innovative approach brings together the two aspects of participation by the local population, and development of the municipalities.

The subjects covered in comprehensive village renewal are aligned with the three pillars of the sustainability strategy (ecology, economy and socio-culture), expanded to include a fourth pillar - the built environment. In addition to the built environment, the new comprehensive village renewal programme will above all also have more room for social sustainability. 


\section{Objectives of comprehensive village renewal}

The objectives of the comprehensive village renewal programme are ensuring and maintaining a good quality of life for all, sustainable development of the municipality and the development of strategies and measures involving the local population. The approach involves promoting endogenous municipality development, i.e. development using local potential and resources (Section 1 of the Burgenland Village Renewal Guideline 2008). The objective is to motivate the local population and involve them in the municipality development. Thus, the social capital in the municipality should be mobilised and reinforced.

Therefore in the village renewal process offers are made that provide opportunities for networking, the joint development of objectives and, building on this, specific project implementation

In order to achieve these objectives, the village renewal programme currently supports process accompaniment, drawing up village renewal guidelines, the planning and development of village renewal projects and the implementation of measures. Central to the new comprehensive village renewal in Burgenland programme is the fact that professional support for the process is provided for. The aim of this, in addition to the operative monitoring of the processes and provision of advice to the municipality, is to mobilise the local population and involve them in the development of strategies.

\section{Those involved in the comprehensive village renewal in Burgenland programme}

The establishment of, and support for, professional monitoring and moderation of the process is a measure that is crucial to the establishment of the comprehensive village renewal instrument (Damyanovic and Reinwald, 2011a). Many different requirements are placed on the process advisers. They have the task of leading the process, structuring it and ensuring continuity of the work. They are responsible for structuring and organising the participation, as well as the organisation, moderation, running and documentation of the various participation events. They form the link between the state administration, the funding bodies, the municipality policymakers and the local population.

Three groups of people are usually involved in LA 21 processes: (1) selected representatives of the citizenship and representatives of the municipality, (2) interested, committed citizens, who take initiatives and actively participate (village renewal group), and (3) all residents of the municipality who wish to be informed about village renewal and who are involved from time to time. These groups are usually organised into different committees and groups. The central body responsible for village renewal at municipality level is the core group, known as the Village Renewal Group. This group is responsible for the control of the processes, their content and their strategic orientation. In addition to this core group there are various working groups, in which citizen's network with one another in connection with specific themes, and specific projects are developed. In addition there are municipality meetings, in which the projects and mission statements are discussed publicly.

\section{Development of a village renewal concept at the heart of the participation process}

Three phases are planned for the village renewal processes. The first phase is the 'information and preparation phase', the second is the 'development of the overall concept of village renewal' and the third is the implementation of the projects. The first phase is to raise the awareness of local residents, offer information on the possibilities of village renewal and cross link different interest groups. In this phase, local residents are informed of the procedures and objectives of village renewal, and a core group is established as the body responsible for the village renewal process. Together with the process advisers, the procedures and process structure are developed and shaped to suit the specific requirements of the municipality. The second phase involves the actual development of the village renewal concept, which is drawn up in a discussion process with the local population. The village renewal concept includes the objectives, an analysis of the municipality's strengths and weaknesses and appropriate areas of action and measures to be taken, based on the four pillars of the village 
renewal programme (social, economic, ecological, spatial structures). A substantial aspect of planning is communication.

\section{Phases of the village renewal process}

\section{Phase $\mathbf{1}$ - Information and preparation}

- Drafting of the participatory planning process concept in close cooperation with the municipality

- Public relations and informing the village inhabitants

- Establishing a "core group" for the process

- SWOT analysis of the municipality

\section{Phase 2 - Development of the village renewal concept}

- Elaboration of the main objectives, future topics and measures for the future development of the muni cipality with the inhabitants

- Presentation and discussion of the village renewal programme

- Selection of "starting projects"

- Decision on the development concept in the municipal council

\section{Phase 3 - Implementation of pr ojects}

- Project devel opment with working groups of inhabitants

- Grant proposals and implementation of projects

Fig 1. Phases in a village renewal process.

The initiation and promotion of projects for the implementation of the village renewal concept is a central element of village renewal. The projects are provided with financial support equating includes obtaining and exchanging information, as well as mutual advice and the weighing up of arguments, mediation and negotiation, in order to be able to define joint objectives (Bischoff et al, 2007) from $30 \%$ to $60 \%$ of the total cost of the project, with a distinction made between concepts and specific project investments. A broad spectrum of measures - social, economic, ecological, structural-spatial - are suitable for support. The central focus, however, next to the structural area, is on support for aspects of the social sphere in the municipality. These include measures for the support of a village's identity, and in the area of education and training. The promotion of community living in the municipality, concentrating on children, young people and seniors, provides the municipalities with numerous opportunities to support social living and networking. These are the essential conditions for reinforcing the social capital of a village.

\section{Demographic and social change as a challenge for the development of municipalities in Burgenland}

The demographic and social changes in the Federal State of Burgenland are manifested in different ways depending on the geographic predispositions and have a strong influence on municipal development.

Burgenland is the most easterly federal state in Austria (see Figure 2). It has borders with Slovakia, Hungary and Slovenia. Burgenland has around 250,000 inhabitants and an area of $3,960 \mathrm{~km}^{2}$. The capital is Eisenstadt. The land is divided into 7 regions with a total of 171 municipalities. The population has been declining for 40 years, especially in municipalities 
close to the border and in the southern parts of Burgenland, while the northern communities, especially those located in the peri-urban (suburban) area of the city of Vienna, experienced growth, strong in parts (e.g. the municipality of Parndorf, from 2,648 inhabitants in 1991 to 4,214 inhabitants in 2012, i.e. +60\%, STATISTIK AUSTRIA 2012).

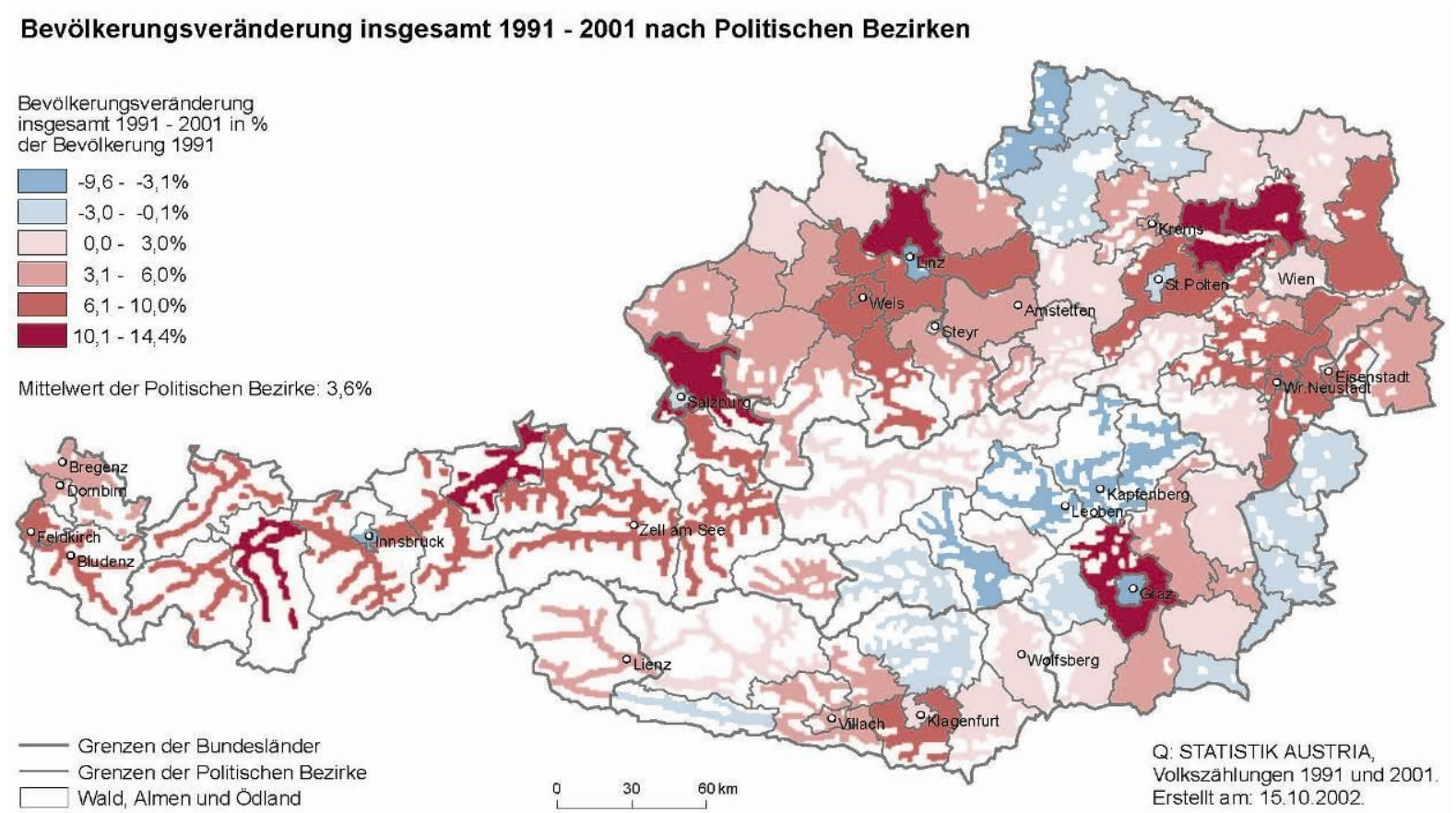

Fig 2. Total population change 1991 - 2001 by political districts (STATISTIK AUSTRIA, 2002).

According to the demographic forecast by STATISTIK AUSTRIA this trend will continue. The more northerly parts of the Federal State will continue to have a population gain. A shrinking population is expected for the southernmost districts of Guessing and Jennersdorf, while an increase is expected in the population sector over 65 years of age (e.g. in the district Güssing, an increase of the share from $21.55 \%$ in 2009 to $36.27 \%$ in 2050 , cf. population forecast from 2009, STATISTIK AUSTRIA, 2009).

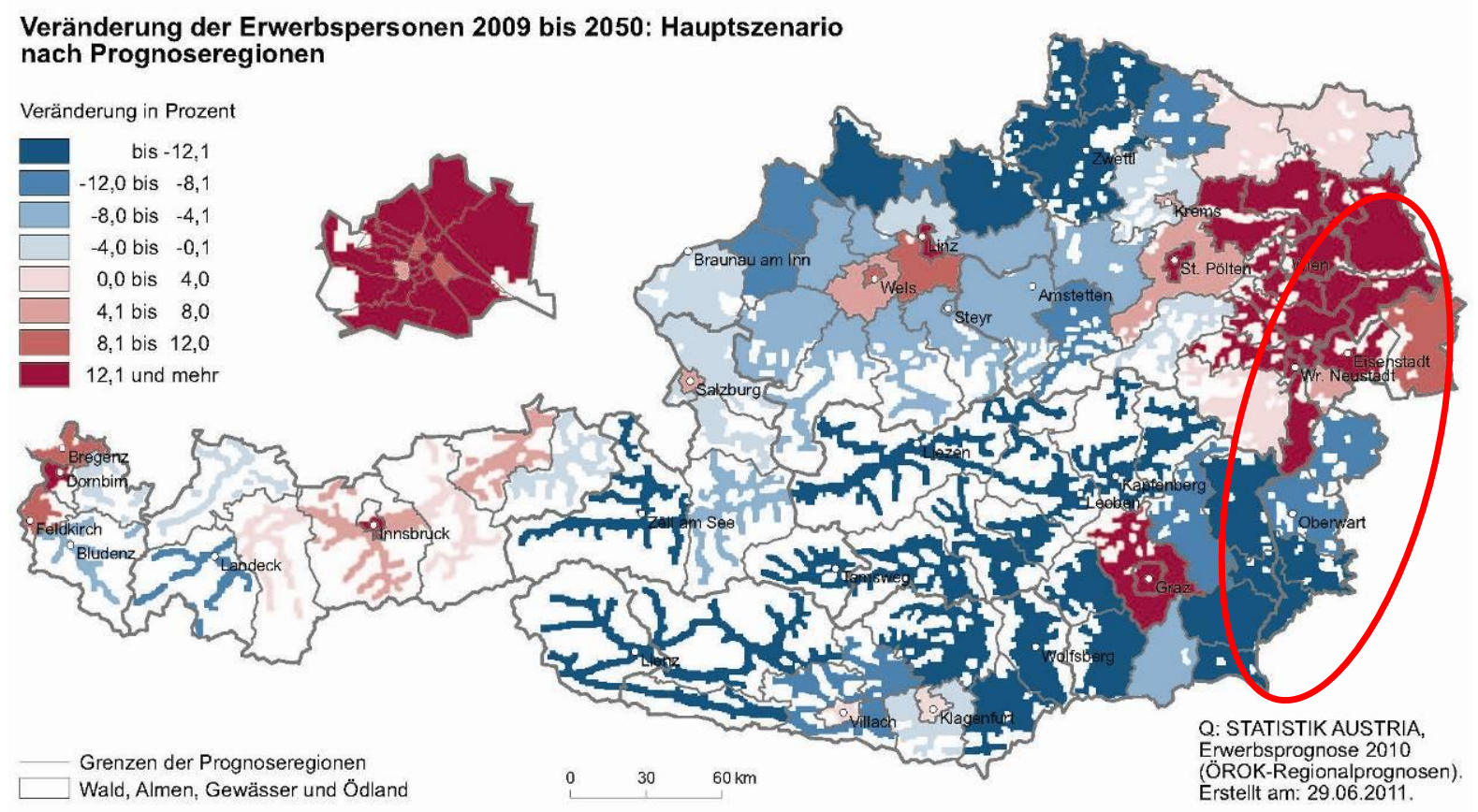

Fig 3. Changes in the labour force from 2009 to 2050: main scenario forecast by regions (source: STATISTIK AUSTRIA, 2011a). 
In addition, the municipalities of southern Burgenland in particular are very small, aggravating the negative demographic trends in this area. About half of the population lives in communities of less than 2,000 inhabitants $(148,844$ out of a total of 280,082 inhabitants, as of 2006 , STATISTIK AUSTRIA). In the district of Guessing, for example, the average number of inhabitants in a municipality is 970 . Also, the proportion of communities with dispersed settlement structures is high (Amt der Burgenländischen Landesregierung (Office of the State of Burgenland) 2011. 190).

Changes in the structure of families and households are also leading to a loss of social capital. The household size in Burgenland, at 2.5 people, is higher than the Austrian average (2.3), but it is constantly declining (2.8 in 1991, 2.6 in 2001 - STATISTIK AUSTRIA, 2001). A sharp increase in single and two-person households in comparison with multiple households can be seen.

In Burgenland there are still twice as many households of three or more generations as the Austrian average (5.9\%), but here, too, sharp decreases have been observed (Jakowitsch, 2011).

A further aspect is outward migration and the high proportion of (weekly) commuters, especially in southern Burgenland. 48,571 Burgenland wage-earners, almost $40 \%$, travel to work outside the Federal state in which they live. Burgenland is the state with the most outward commuters in Austria (STATISTIK AUSTRIA, 2011b). This means that the time these people spend in the municipality is reduced, as are the possibilities for them getting involved in its development. Permanent outward migration (above all of young Burgenland residents) also leads to a loss of social capital.

\begin{tabular}{|l|r|r|r|r|}
\hline \multirow{2}{*}{} & \multicolumn{2}{|c|}{1971} & \multicolumn{2}{c|}{2001} \\
\cline { 2 - 5 } & Absolute & \multicolumn{1}{c|}{$\%$} & \multicolumn{1}{c|}{ Absolute } & \multicolumn{1}{c|}{$\%$} \\
\hline Single-person households & 6,711 & $9.2 \%$ & 27,679 & $26.1 \%$ \\
\hline Two-person households & 12,628 & $17.3 \%$ & 29,876 & $28.1 \%$ \\
\hline Three to four person households & 31,118 & $42.5 \%$ & 39,297 & $37.0 \%$ \\
\hline Households of 5 or more people & 22,689 & $31.0 \%$ & 9,369 & $8.8 \%$ \\
\hline Total households & 73,146 & $100.0 \%$ & 106,221 & $100.0 \%$ \\
\hline
\end{tabular}

Tab 1. Households in Burgenland (Source: STATISTIK AUSTRIA, 2001 own representation).

The municipalities of southern Burgenland in particular have to face the challenge of maintaining quality of life - social life as well as services of general interest - despite a shrinking and ageing population. The loss of social life begins with the loss of establishments that are places of communication for the community. If village centres and high streets lose their attractiveness due to businesses closing down, restaurants there also close and important centres of communication in the village or town are lost. Associations have difficulty in finding new members.

These social changes are already having a significant impact on the development of the municipality. If there are fewer inhabitants who are involved in networks and who make an independent effort to ensure the development of the municipality, its quality of life will change. As family structures change, many are referred for outside assistance. Above all, a loss of associations often represents a challenge for the municipalities, as it is not only leisure activities for individuals that are lost, but also the structures that create the networks and infrastructures essential to the social capital approach. Changes in community life also have effects on the municipalities. There is less help between neighbours and other forms of mutual assistance, leaving a gap which has to be filled by the municipality. It also becomes increasingly 
difficult to find people, especially young people, to get involved in the community, and volunteers to devote time to developing the municipality.

\section{Empirical knowledge - village renewal and social capital}

In a study conducted in 2011, the effects of the new comprehensive village renewal were determined. At the time the study was carried out, over 100 of the 171 Burgenland municipalities had already become involved in village renewal.

The study serves as a basis for the continuing further development of the comprehensive village renewal programme in Burgenland and had the following objectives: (1) the quantitative collection and evaluation of fundamental key data concerning the village renewal municipalities; (2) the qualitative ascertaining and evaluation of the effectiveness and effects of the comprehensive village renewal by means of interviews and (3) the drafting of recommendations and possible measures for quality assurance in comprehensive village renewal.

This chapter of the paper examines the results of the study using the social capital concept. When reflecting on the results of the study, the following research questions are central:

(1) What findings can be derived about social capital in the municipalities from the results of the study? (2) What contribution has the comprehensive village renewal programme made to date to the development of social capital? (3) What potential does the comprehensive village renewal programme have for increasing social capital?

The study on the comprehensive village renewal programme in Burgenland covers two main areas. A quantitative evaluation was carried out of the fundamental key data for the comprehensive village renewal in Burgenland. Applications, documents and various reports and papers from the Department for Village Renewal of the Federal State of Burgenland were made available as a basis for this evaluation.

The second focal point was formed by interviews, based on a specific set of guidelines, with those involved in the village renewal core groups, i.e. the group which is responsible for the implementation of the village renewal process. These groups usually included mayors, members of the municipal council, representatives of the associations and active citizens. Interviews based on a specific set of guidelines were carried out with 15 people from 7 municipalities.

The impact of an instrument such as the comprehensive village renewal programme cannot be described or interpreted purely quantitatively. A combination of both qualitative and quantitative survey and evaluation methods, together with a comparison of the quantitative and qualitative results, was therefore chosen in the form of triangulation (Flick et al., 1995). Triangulation refers to a combination of methods used to analyse the same phenomenon. The use of several methods improves the validity of statements made through cross-checking.

The method of interviews centred on specific problems was used to check the impact of the comprehensive village renewal in Burgenland (Lamnek, 1995). In order to be able to trace the results intersubjectively, work was done with semi-standardised guide interviews (Mieg and Näf, 2008). Based on the trends obtained from the quantitative evaluations, topic areas and focus points were determined together with the client for collecting previous experience of comprehensive village renewal and the implementation of village renewal projects.

\section{Involvement of the municipalities in village renewal}

A quantitative evaluation of the documents of the Department for Village Renewal of the Federal State of Burgenland showed that around $60 \%$ of the Burgenland municipalities are committed to village renewal. There were clear differences between the regions. 

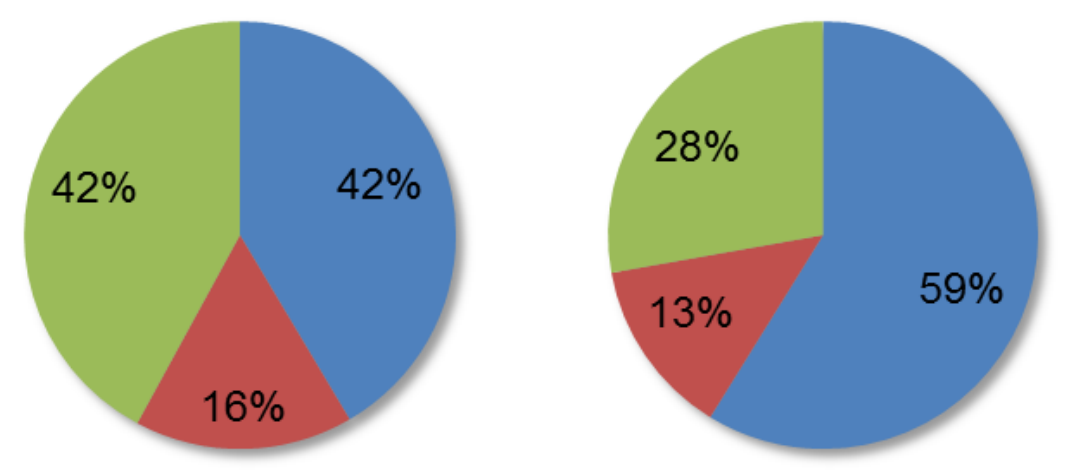

- LAG Nordburgenland

- LAG Mittelburgenland

- LAG Südburgenland

Fig 4. The distribution of the municipalities on the LAGs ("Local working group" - Regional assembly within the rural development programme) (left) and distribution of municipalities taking part in the village renewal programme (right).

The reasons for this differences discussed during the interviews were both financial the southern regions and municipalities (Central Burgenland LAG (LAG Mittelburgenland) and Southern Burgenland LAG (LAG Südburgenland) tended to have fewer economic resources and social - there are ever fewer people in these regions who are actively involved in development of the municipalities. An analysis of the funding amounts for projects implemented as part of the village renewal process, evaluated by region, showed a similar pattern. The northern region implemented substantially more projects and drew on substantially more funding.

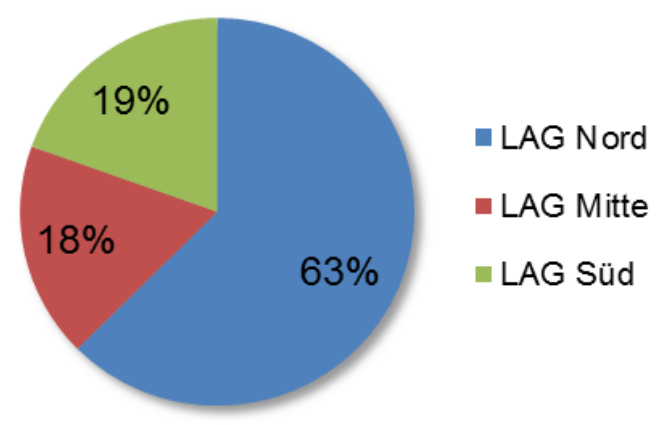

Fig 5. Distribution of funding amounts for individual projects to the regions.

In the discussion of these results, the question arose of the reasons that could be responsible for these differences. A further possible reason for the differences discussed was the commitment and participation of the local population - the social capital.

Three areas of the study in particular enable conclusions to be drawn about local social capital in the municipalities and the local social networks. (1) A differentiated representation of the different types of participation, (2) the subject areas dealt with by the village renewal groups in the municipalities and (3) the capacity of the village renewal project to show what groups and networks are present at municipality level and what areas are important to the municipality. 


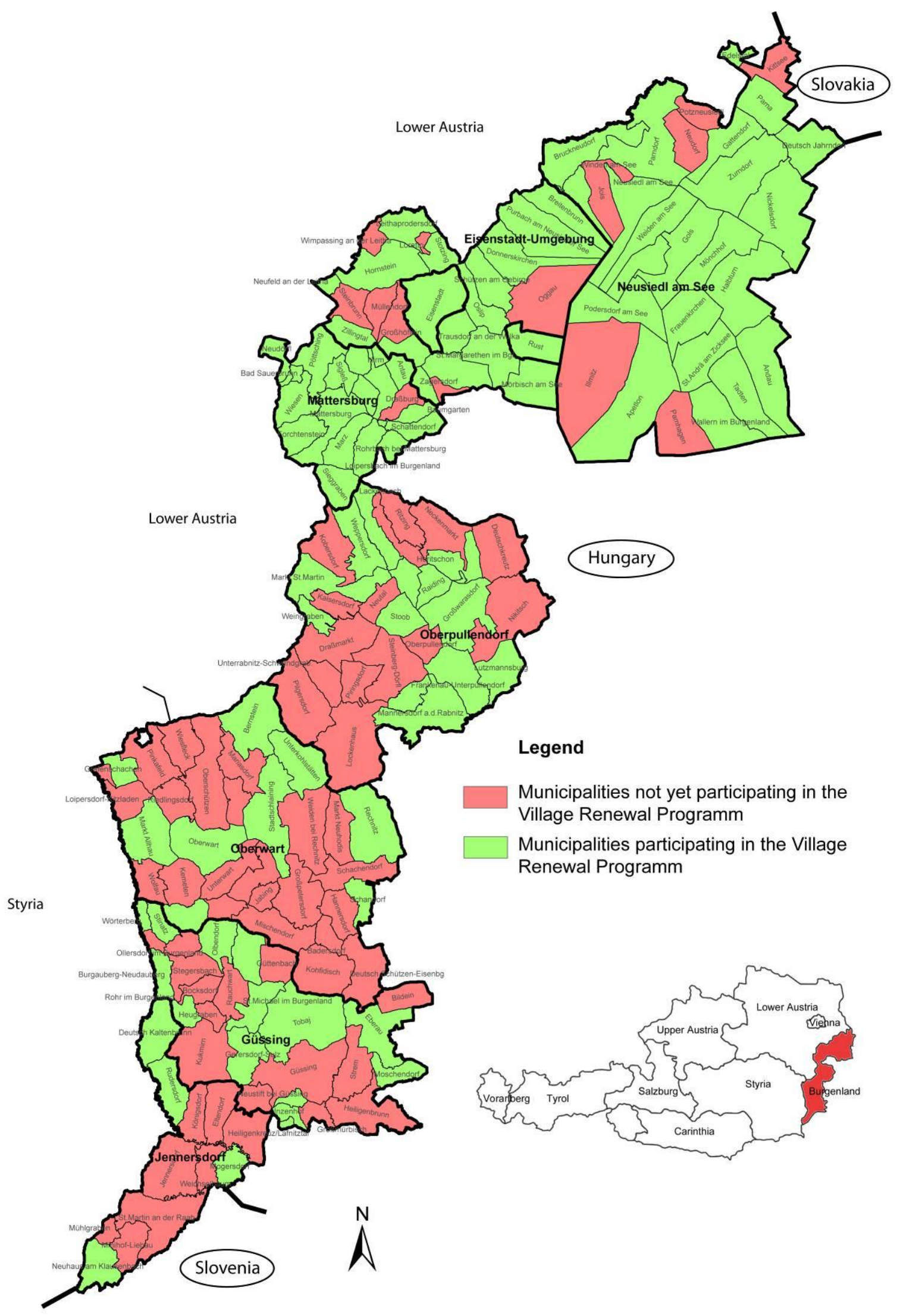

Fig 6. Municipalities taking part in the village renewal programme (as of 2010; Source: Base map Federal state of Burgenland). 


\section{Participation of people}

The differences in participation of the population of the different municipalities were analysed. Unfortunately, no comprehensive data on this could be found as no prescribed documentation was demanded on the issue of who was involved at which level. A single evaluation form completed by the process advisers was all that could be used as a basis for the data. A total of 52 municipalities were included in the comparison.

An average of around 200 people per municipality got involved in the village renewal processes by taking part in discussions, as members of the core group or in working groups. Comparatively higher participation was observed in southern Burgenland ( 270 people), while the level was lower in northern Burgenland ( 130 people). These differences were explained in the interviews conducted later, by the fact that participation in associations, and with it commitment to the community, enjoys greater commitment from the inhabitants of southern Burgenland despite the low population numbers of the smaller municipalities. The evaluation showed that it was not the level of participation that was the decisive factor for the number of projects.

Men and women are more or less equally involved in the overall village renewal processes. A differentiated picture emerges if the involvement in the village renewal 'core group' is also considered gender-specifically. The 'core group' who lead the process locally are made up on average of $70 \%$ men and $30 \%$ women. Fewer women are therefore involved in the core groups in comparison with the total involvement in village renewal (working groups on projects, participation events, etc.). The overall high participation by women in village renewal - in contrast to institutionalised local authority politics (Reinwald et al., 2011) - is therefore not reflected in the management positions and core groups. Reasons given for this include the fact that family commitments and care obligations mean that women have difficulty committing to regular participation in events over an extended period and therefore do not take managerial posts. Another factor was the fact that the individual party-political composition of the core groups indirectly also reflects the (male-dominated) local council, and so fewer women are represented.
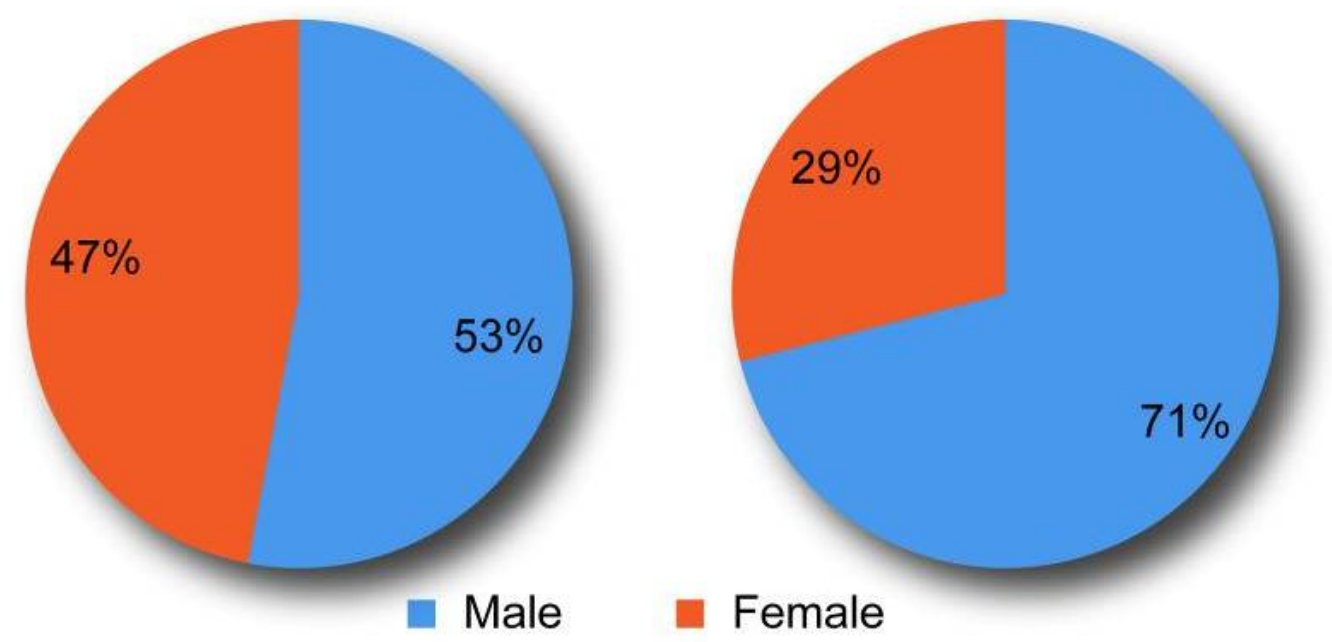

Fig 7. Comparison of the participation of women and men in the overall village renewal processes (left) and the 'core group' (right).

\section{Topics for village renewal}

The basis for the analysis of this subject area is formed by the village renewal concepts and explanatory reports on the village renewal processes. For the content of the current state analyses a total of 53 village renewal concepts were considered, of which the SWOT analyses of 46 were evaluated. In most municipalities a current-state analysis was carried out by the process adviser. This describes the current situation in the municipality with regard to various subject areas. In most cases an analysis of the strengths and weaknesses of the municipality was drawn up as a result of citizen participation. 
In the case of almost all the current-state analyses, the socio-demographic data such as population development and population structure were evaluated. A central aspect of the current-state analyses for around $40 \%$ of the municipalities was the preoccupation with associations and the social scene of the municipality. These aspects were even more important in the analyses of strengths and weaknesses carried out by the local residents. Over $80 \%$ of the municipalities dealt with "associations, social, leisure and culture" as a special subject in their analyses of strengths and weaknesses.

The strong preoccupation with the subject of social interaction at the analysis stage shows that social life and the associated social capital is of central importance to the future development of municipalities, and that the municipalities themselves see the support and promotion of this as a central task for the future.

\section{The implementation of the core group is crucial for a successful village renewal process}

The largest sector of those involved in the core groups, alongside political representatives, was usually made up of active members and committee members of associations. Further typical groups are named as members of the clergy, business people, farmers and senior citizens' representatives. The substantial representation in the core groups by people active in other spheres of community life and local development, such as association officials, members of lobbies, etc. - in other words people with a substantial social capital - means that "active community members are also active in the village renewal process". These people have proved to be crucial agents of village renewal in the municipality.

It has also been observed in the municipalities that a range of different skills is needed within the village renewal groups - such as skills in the area of public relations, in the area of the formulation of strategic objectives and in the area of "practical work". Gender-specific differences have also been observed here. Women contributed far more to the social sphere of the community, for example in areas such as youth, the generations, care of the elderly, village services and neighbourly help and support. Men were traditionally represented in the areas of business, construction and planning, infrastructure and traffic.

\section{The (implementation) projects of village renewal}

Conclusions about the social capital within village renewal can also be drawn from the projects that are developed and implemented within the scope of village renewal. The idea is that the projects also indicate which networks have come forward and achieved results. Above all, priorities can be observed from a comparison of projects actually implemented with those proposed.

As a constituent part of the overall village renewal concept, preliminary projects were specified by the municipalities, which were to be implemented soon. A random sample of 30 overall village renewal concepts with a total of 436 preliminary projects were evaluated and the central emphasis of each ascertained. More than half of the projects could be classified as relating to construction, or the shaping of the village's appearance.

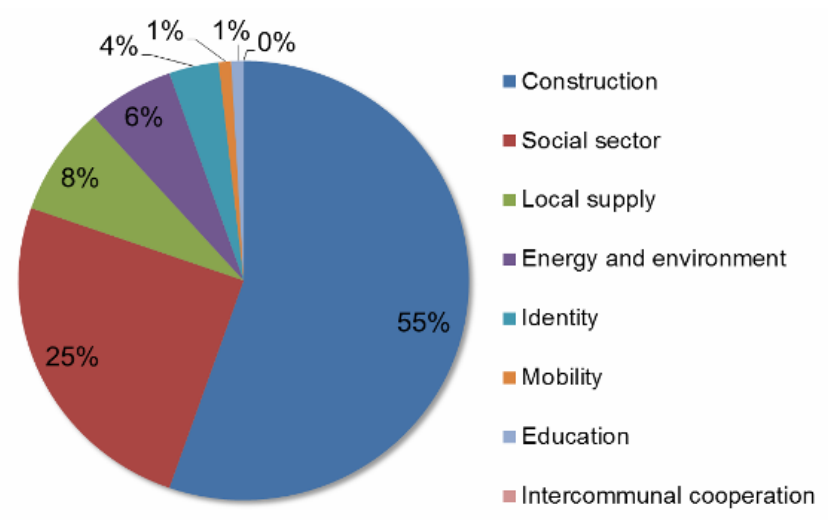

Fig 8. Distribution of the initial projects between the different categories. 
However, initiatives in the social sphere did play a relatively important part, accounting for a quarter of the preliminary projects. Of the total of 82 actually authorised, funded and implemented village renewal projects in place at the time the study was carried out, an even greater proportion of the projects could be assigned to the construction and planning sector. Projects in the social sphere were almost completely lacking. The comparison shows that although many projects that can be allocated to the social sphere were proposed, the majority of those actually implemented were investment projects.

At first glance it could be seen that "classic" themes and projects, such as those that had already arisen in the traditional forms of village renewal, dominated, and therefore that traditional networks and groups with their social capital were successful. It was expected that the linking of village renewal with the LA 21 Strategy, by means of which comprehensive village renewal, including in particular the social sector of municipality development and thus new groups and people who would get involved in village renewal, would be addressed. The possibility of using the participation process to bring together new interest communities and form groups should lead to a greater number of measures being implemented in this area.

This fact was also discussed in the course of the interviews with experts, with the outcome that projects in the social sphere were quite definitely implemented in the municipalities, but in most cases these did not require funding and so did not appear in the official statistics.

It was apparent that a broad spectrum of organisational and management projects were implemented as a result of the village renewal processes. In most cases these organisational projects are those that "only need to be organised". Examples of organisational projects from the municipalities surveyed are: wood fuel pool - bringing together suppliers/users, organisation of shopping trips, food exchange - offering unused garden space, 60+ helping $80+$, young people helping the elderly with computers and mobile phones, multigenerational meeting place/club - young and old coming together, village festivals, multicultural initiatives - Turkish afternoon, carers' working group, etc.

However, skills (management and organisational expertise) and structures (networks, groups of people with similar interests) need to be present or developed accordingly at municipality level. This is where social capital in the municipalities comes into its own. Organisational projects demonstrate social capital as they depend exclusively on networks and the (coordinated) use of people. It has also been shown that new people and subject areas are being addressed by village renewal.

\section{Discussion and Conclusion}

The actual study did not explicitly deal with the evaluation of the social capital. On the one hand, statements could be made in the paper on the analysed empirical material concerning the formation of local social capital. On the other hand, the deficits of the investigation and the instrument of comprehensive village renewal are stated and the outstanding research need concerning the social capital concept in comprehensive village renewal and instruments in the implementation within the participative process are clarified.

\section{Possibilities and potential of the comprehensive village renewal programme for building up social capital}

Building up social capital is a prerequisite for a sustainable village renewal process. The village renewal process supports in particular the group level (meso), which is closely connected to the individual (micro) level. Nevertheless, it also depends on the organisational (macro) level (Putnam 2003, Hanke 2011). The village renewal process supports the local people in mobilising and increasing their social capital on the group level, as institutional structures are created that support cooperation and bring different groups together (Wiesinger, 2007). Local social capital for a successful village renewal process in the municipalities depends on existing social structures such as associations. Voluntary work and associations still work very well, especially in the southern Burgenland municipalities. Those municipalities with a high level of incomers sometimes find it harder, as there is a lack of established networks and structures 
(Damyanovic and Reinwald, 2011). Well-networked people, people with a high individual social capital, are very often the primary agents of village renewal in the municipalities (Elbe, 2011).

However, changes in family structures, demographic changes and the resultant altered challenges for the municipalities are viewed as a central task for the future by all municipalities. Villages are changing, and mutual assistance between neighbours needs to be reorganised. The diagnosis is that local social capital is reducing in the municipalities. It is, however, a "renewable resource", that can be built up by local people taking part in the village renewal process. But to do this, municipalities need financial resources and personal support.

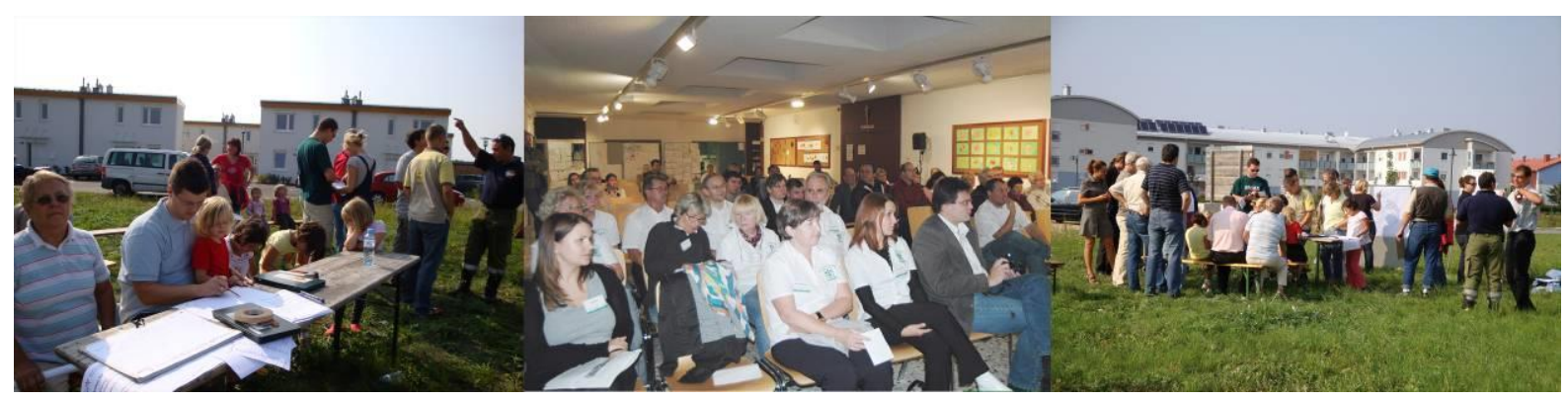

Fig 9. Strengthening social capital by bringing people together.

\section{Creative ways to build up social capital}

Village renewal has the potential to become a hub for social contacts and for establishing new networks of people with similar interests (Falk and Kilpartrick 2000). In order to do this, however, new skills and support structures need to be developed. The process advisers have a central role in implementing a sustainable village renewal group. The process adviser must organise the participative process in such a way that existing forms of capital at the micro and meso levels, which support the village renewal objectives, are brought together. However to this end the existing social capital of the villages needs to be precisely analysed and a strategy developed for the process. An important result of the study is to address the topic of local social capital more effectively in future.

Starting with an analysis of existing social structures and moving through the organisation of participation and the appointment of management committees, to the development of initiatives and specific projects, the building of social capital needs to be explicitly addressed and promoted. The readiness to engage in community life has been described as tending to decrease in all municipalities. Those who are committed are already involved in numerous associations and initiatives and are often already overloaded. Village renewal process can contribute by mobilising additional people, establishing networks and thereby building up more social capital.

It is only through community networks and a high social capital among those involved that specific projects can be implemented to improve the quality of life in the municipalities, which is an important objective of the village renewal policy. Ever more people are needed to implement village renewal projects successfully.

Awareness also needs to be raised in the municipal councils. The focus should not only be on large-scale projects such as old people's homes, but also on initiatives for changing and repositioning mutual assistance among neighbours. An important contribution can also be made by the active networking of groups of the population (e.g. incomers, commuters, carers, etc.) who face similar challenges to one another. Initiatives that build up local social capital and the increase thereof have a high "return". By building up more social capital in the village renewal group, more and better projects can be implemented, thereby meeting challenges such as that of demographic change. The structure of the village renewal group is crucial to sustainable implementation.

An important factor for success is that as many different groups as possible from within the municipality are represented in the village renewal group. This enables new topics, different points of view and, above all, new people and their individual social capital to be incorporated in 
the development of the municipality. The following criteria are essential to ensuring that the social capital is available to the group as a whole. The village renewal group must have good, bridge-building capital in order to be able to implement the village renewal objectives (Elbe, 2011). The village renewal group must have positive experience in working cooperatively and be able to define itself on the basis of shared content. Trust within the group is a further criterion for sustainable cooperation, both during and after completion of the process. It is also important for the implementation of the objectives that the group is open to new members and that members are also free to leave. The investment of people's own resources and time in the group is made on the assumption that the remaining members behave in such a way that their own interests are better represented and promoted by the provision of substantially more resources than could be achieved alone (Elbe, 2011:86).

It is also important to remain open, in order to prevent exclusion mechanisms from kicking in. It is particularly important to take account of gender and interest group-specific requirements here. Village renewal can build up social capital as new structures are created that enable people to meet, make contacts and establish networks, and mutual interests and objectives are brought together, from which new projects arise.

\section{Creating support structures}

The administrative authorities charged with village renewal can also make a contribution by supporting networks between village renewal groups and municipalities at a wider regional level. It is often not possible to solve problems faced by individual municipalities alone, and in such cases networking can provide important support. In Burgenland, for example, a series of events has been organised that supports networking of this kind. In a dedicated event - Social Capital and Village Renewal - successful examples of projects implemented in practice were put forward and methods for the measurement, evaluation and promotion of social capital in the municipalities were demonstrated (http.//www.zukunftburgenland.at).

Village renewal makes a contribution to empowerment and self-help in meeting the challenges of demographic change and using the inherent potential of municipalities and regions, which to a great extent is built on the local social capital of their inhabitants. Networks, such as those created through the village renewal process, are the basis for social cohesion because they enable people to cooperate with one another.

\section{Outlook and need for further research}

The current need for research lies above all in the area of refining the social capital concept for a participative village renewal process and describing the various forms of capital and the structure of their effects in greater detail, in order to understand the mechanisms better and take account of them more effectively in the participative planning process. The reflections of the study have shown that the availability of local social capital to village renewal groups provides substantial support for sustainable implementation. But in order to estimate the social capital precisely before and after the start of the process, the process advisers must be given methods and tools to enable them to measure and make visible the capital of the local population considering gender, age, social and cultural background (Grootaert and Van Bastelaer, 2002; Norris and Inglehart 2003). One way of making social capital visible is to examine who is involved in community life, how and why (Putnam, 1993, Lederer, 2005). More in-depth analysis of networks at municipality level is also crucial at subsequent stages, in order to develop specific measures for the support of rural areas (Elbe, 2011).

\section{Acknowledgements}

The study on the comprehensive village renewal programme was financed by the UNSER DORF [Our Village] association. 
[1] Axhausen, K. W. (2008). Social networks, mobility biographies and travel survey challenges. Environment and Planning B: Planning and Design 35(6), 981-996. Doi: 10.1068/b3316t.

[2] Bischoff, A., Selle, K. \& Sinning, H. (2007): Informieren, Beteiligen, Kooperieren. Dortmund: Dorothea Rohn Verlag.

[3] Büchel-Kapeller, K., Hellrigl, M. \& Lederer, M., eds. (2010). Freiwilliges Engagement und Sozialkapital. Bregenz: Büro für Zukunftsfragen.

[4] Sozialkapital. Das Leben im Netz sozialer Beziehungen (2010). Wien: Bundes-ministerium für Unterricht, Kunst und Kultur, Bundesministerium für Land- und Forstwirtschaft, Umwelt und Wasserwirtschaft.

[5] Bourdieu, P. (1983). Ökonomisches Kapital - Kulturelles Kapital - Soziales Kapital. In Kreckel, R., ed., Soziale Ungleichheiten (pp. 183-198). Göttingen: Schwartz.

[6] Bourdieu, P. (1991). Language and Symbolic Power. Cambridge: Polity Press.

[7] Coleman, J. S. (1988). Social Capital in the Creation of Human Capital. The American Journal of Sociology. 94, 95-120.

[8] Dangschat, J. \& Breitfuss, A. (2000). Lokale Agenda 21 in Wien. Von der Betroffenbeteiligung zur Akteurskooperation. Wien: Institute for Urban and Social Research at the University of Vienna.

[9] Damyanovic, D. \& Reinwald, F. (2011). The comprehensive village renewal program in Burgenland [Research Study]. Wien: Universität für Bodenkultur.

[10] Damyanovic, D. \& Reinwald, F. (2011a). Umfassende Dorferneuerung im Burgenland als Planungsinstrument zur nachhaltigen Entwicklung des ländlichen Raumes - eine Chance?. Zoll+ Österreichische Schriftenreihe für Landschaft und Freiraum 18, 18-25.

[11] Elbe, J. (2011). Die Wirksamkeit von Sozialkapital in der Regionalentwicklung. Erprobung eines anwendungsorientierten Analysekonzepts am Beispiel des Modellvorhabens „Bioenergie-Regionen“. Aachen: Shaker Verlag.

[12] Faar, J. (2004). Social Capital. A Conceptual History. Political Theory. 32(1), 6-33. Doi: $10.1177 / 0090591703254978$.

[13] Falk, I. \& Kilpatrick, S. (2000). What is social capital? A study of interaction in a rural community. Sociologia Ruralis 40(1), 87-110. Doi: 10.1111/1467-9523.00133.

[14] Field, J. (2008). Social Capital. Abingdon: Ashgate.

[15] Flick, U., Kardorff, E. v., Keupp, H., Rosenstiel, L. v. \& Wolff, S., eds. (1995). Handbuch qualitative Sozialforschung. Grundlagen, Konzepte, Methoden und Anwendungen, $2^{\text {nd }}$ ed. Weinheim: Beltz.

[16] Gehmacher, E. (2009). Sozialkapital - Chancen und Grenzen der Methodik SWS Rundschau - Die Zeitschrift der Sozialwissenschaftlichen Studiengesellschaft 49(1), 103109.

[17] Groottaert, C. \& Van Bastelaer, T. (2002). Understanding and Measuring Social Capital. A Multidisciplinary Tool for Practitioners. Washington: World Bank.

[18] Hanke, M. (2011). Sozialkapital in partizipativer Stadtentwicklung am Beispiel der Lokalen Agenda 21 Wien. [Diploma Thesis] Universität Wien.

[19] Husák, J. (2012). Synergy of Social and Human Capital in rural development - Czech and German Cases. European Countryside 4(4), 240-250. Doi: 10.2478/v10091-012-0026-3.

[20] Jacob, J. (1961). Tod und Leben großer amerikanischer Städte. Berlin/Wien: Ullstein. 
[21] Jakowitsch, J. (2011). Frauen im Burgenland Bericht 2011. [Research Report]. Eisenstadt: Burgenländische Forschungsgesellschaft.

[22] Lamnek, S. (1995). Qualitative Sozialforschung, Vol. 2 Methoden und Techniken $3^{\text {rd }}$ ed. Weinheim: Psychologie Verlags Union.

[23] Lederer, M. (2005). Gemeinsam oder Einsam? Von der Funktion und Wirkung von Sozialkapital bei unterschiedlichen Theoretikern. Bregenz: Büro für Zukunftsfragen.

[24] Mieg, H. A. \& Näf, M. (2006). Experteninterviews in den Umwelt- und Planungswissenschaften. Lengerich: Pabst Science.

[25] Norris, P. \& Inglehart, R. (2003). Gendering Social Capital: Bowling in Women's Leagues' Keynote address for the conference on Gender and Social Capital, University of Manitoba, May 2-3, 2003.

[26] Putnam, R. D. (1993). Making Democracy Work. New Jersey: Princeton University.

[27] Putnam, R. D. (1995). Bowling alone. America's Declining of Social Capital. Journal of Democracy. 6(1), 65-78.

[28] Putnam, R. D. \& Gross, K. A. (2001). Einleitung. In Putnam, R. D., ed., Gesellschaft und Gemeinsinn. Sozialkapital im internationalen Vergleich (pp. 15-45). Gütersloh.

[29] Reinwald, F., Damyanovic, D. \& Weber, F. (2011). Frauen in der burgenländischen Gemeindepolitik. [Research Report]. Eisenstadt: Amt der Burgenländischen Landesregierung.

[30] Statistik Austria (2001). Haushaltsgrößen im Burgenland, Volkszählung 1971 und 2001. Accessed from http://www.statistik.at/web de/statistiken/bevoelkerung/haushalte_ familien_lebensformen/index.html.

[31] Statistik Austria (2002). Bevölkerungsveränderung insgesamt 1991 - 2001 nach politischen Bezirken, Datenbasis Volkszählung 1991 und 2001. Accessed from https://www.statistik.at/web_de/services/interaktive_karten/index.html.

[32] Statistik Austria (2009). Kleinräumige Bevölkerungsprognose für Österreich 2010-2030 mit Ausblick bis 2050 („ÖROK-Prognosen“), Teil 1: Endbericht zur Bevölkerungsprognose. Accessed from: https://www.statistik.at/web_de/kleinraeumige_bevoelkerungsprognose_fu er_oesterreich_2010-2030_mit ausblick_051902.pdf.

[33] Statistik Austria (2011a). Erwerbsprognose 2010, ÖROK Regionalprognosen. Accessed from: www.statistik.at/web_de/static/veraenderung_nach_prognose_057105.pdf.

[34] Statistik Austria (2011b). Mehr als 500.000 Erwerbstätige verlassen zur Arbeit ihr Wohnbundesland. [Press Release 10.124-270/11]. Accessed from: http://www.statistik.at/web_de/presse/060078.

[35] Statistik Austria (2012). Ein Blick auf die Gemeinde online. Accessed from http://www.statistik.at/blickgem/gemDetail.do?gemnr=10717parndorf.

[36] Tiefenbach, J. (2011). Historischer Atlas Burgenland. Eisenstadt: Amt der Burgenländischen Landesregierung.

[37] Wiesinger, G. (2007). Social capital and rural development. In Oedl-Wieser, ed., Zeitreisende im ländlichen Raum (97-112). [Research report no. 57]. Wien: The Federal Institute for Less Favoured and Mountainous Areas.

[38] Worldbank (2001). World Development Report 2000/2001 - Attacking Poverty. Washingtion/New York: World Bank/Oxford University Press. 